\title{
EVALUATION OF THE OSCE IN THE PRIMARY HEALTH CARE SITUATION.
}

\section{P.M. GARDE}

\section{INTRODUCTION}

The traditional methods of examination by long written questions, case presentations and orals have given rise to difficulties with both candidates and examiners, especially when they have been inexperienced and untrained.

The new method of examination as described by the Medical School of the University of Cape Town, the Objective Structured Clinical Examination (OSCE), was therefore evaluated in the KwaZulu Primary Health Care (PHC) nursing examinations in February, 1984.

\section{METHOD}

The OSCE covered three hours, with twenty stations of ten minutes each. The stations were as follows:

1. History of a moderately malnourished child

2. Examination of the same child

3. Oral examination of the findings and management of 1 and 2

4. Rest

5. Examine and record an adult respiratory system

6. Antenatal clinic card risk factor assessment and management

7. Delivery record, assessment of maternal distress and management

8. Urinalysis of haematuria, management at 3 months and 5 years

9. Differential diagnosis after an abdominal examination with ascites and hepatomegaly

10. Recognition and management of dehydration from a slide

11. Rest

12. Approach to fatigue and headaches in an obese patient

13. Tuberculosis out-patient card assessment and management

14. Analysis of community statistics on malnutrition

15. Assessment of community, patient and clinic factors in uncontrolled chronic obstructive lung disease

Dr. P.M Garde

Convenor, P.H.C. Examination

Board, KwaZulu

(Present address: Community Obstetrics, KwaZulu Department of Health and Welfare, 46 Mkhula Road, Westville, 3630)

\section{OPSOMMING}

Die Objektiewe Gestruktureerde Kliniese Evaluering (OGKE) is gebruik in die finale Primêre Gesondheidsorg-eksamen van 21 verpleegkundiges in KwaZulu.

Al die eksaminatore en almal behalwe een van die kandidate was van mening dat die OGKE die beste van al die beskikbare eksamenstelsels is.

Die OGKE word vir die evaluering van kliniese vaardighede by alle lede van die mediese, verpleeg- en gesondheidspan aanbeveel.

16. History and differential diagnosis in irregular vaginal bleeding

17. Rest

18. Worms identification and management

19. Examination of an infant with pyrexia, and oral test

20. Convulsion management

Each internal and external examiner and candidate completed a questionnaire after the OSCE.

\section{RESULTS}

\section{Candidates}

Twenty out of 21 candidates preferred to OSCE to previous examination techniques.

The one who did not, had major emotional disturbance and misread two questions. Despite this, she did exceptionally well in others, and passed the examination.

There was no correlation between individual station assessment and marks achieved, except for one having being too long and another too difficult (this was subseqently removed from the marks).

\section{Examiners}

All thirteen examiners preferred the OSCE. Reasons included were: wide coverage of subject matter and skills: part of a continuing learning process for candidates and examiners; more objective and fair; economical in time: better relationships. It was thought more difficult to set up.

\section{Correlation with internal assessments.}

The OSCE confirmed the $100 \%$ expected pass rate. There were however no honours, despite five expected by the trainers.

\section{RECOMMENDATIONS}

- All stations should be tested during class tests before inclusion in the final examination, and a bank of stations built up. This will decrease preparation time and avoid ambiguous wording and laments of too little time (applicable to most examinations).

- Stations should be weighted with marks according to their clinical significance.

- Adequate time should be allowed for orals, preferably incorporated into all clinical stations. This would enable examiners to assess borderline cases, whether for failure or honours, in greater depth.

It appears to be more difficult to achieve high marks in an OSCE as it covers a wider field than the conventional examination and the candidate has to achieve $70 \%$ or more at virtually every station.

Orals may therefore play a valuable role in assessing this.

- All stations should reflect actual situations, rather than simulated tests for example, a patient rather than a slide; a real patient for a test in history taking (rather than an examiner. especially in Gynaecology)

- The final results should include the internal assessments of the trainers to determine whether each nurse would be effective in a clinic setting. This would also be of benefit in true cases of extreme examination anxiety. where the nurse would be assisted by a personal relationship with the examiner and oral probing

- The physical arrangement is most important for smooth operation. This includes clear numbering of stations in sequence (including rests); clear instructions to candidates about the direction, obligatory rests, and leaving station material behind as they move along; avoiding too many people examining at one station. One person should be responsible for 
time-keeping and ensuring a smooth change-over.

- The complaints that the OSCE allowed no choice in questions or time to add information which you remembered subsequently, were not considered valid. We are examining for safety in a clinic situation where you have no choice as to patient, presentation or skills. Neither will you be safe if you remember something vital after the patient has gone home - 30 kilometres into the bush.

\section{CONCLUSION}

The OSCE technique is assessed as the best method to check objectively and comprehensively whether health personnel can cope safely in primary health care situations.

\section{ACKNOWLEDGEMENTS}

Acknowledgement is expressed to the participants in the evaluation process and to the KwaZulu authorities for permission to publish.

\section{OSCE Continued from p. 35}

Certain students also found it difficult to role play.

The scoring at the following four stations was generally very low:

- documentation

- teaching by precept and example

- calculation of medication dosages

- CPR

\section{FEEDBACK TO STUDENTS}

It was not possible to give feedback to the students on the same day as they had to return to their allocated wards and departments. It would have been most difficult to arrange for all the students to again leave the areas to which they had been allocated. so it was decided to do the report back when the students were back at College.

In terms of the S.A. Nursing Council Regulation No R879, as amended, the marks are not to be divulged (SANC p. 6-7) The report back was very generalised and clearly, this is educationally unsound.

\section{FEEDBACK FROM STUDENTS}

The students were most enthusiastic and appeared to have enjoyed the experience, despite their initial apprehension. A few felt that the time allowed for some stations and for movement between stations was inadequate. On the whole it was said to have been a fun experience.

\section{FINDINGS}

- The geographic situation of the Nursing Education Department was a problem as equipment had to be fetched from the wards and carried up many stairs as there is no lift in one area.

- Simulation is not as effective as real situations.
- Large student numbers pose problems.

- A considerable amount of time was spent on the preparation of the stations, questionnaires and checklists.

- The confidential nature of the examination system is unsatisfactory.

- Inexperience in designing questionnaires and checklists made it more difficult.

\section{ADVANTAGES OF THE OSCE}

- It is objective, valid and reliable.

- All participants found it very stimulating and it proved to be a marvellous team building exercise

- Problem areas were identified and attention has since been given to those aspects of the teaching programme.

- A bank of questionnaires and checklists has been started.

Undoubtedly, the advantages far outweigh the disadvantages.

\section{RECOMMENDATIONS}

Further experimentation and research into the design of questionnaires and checklists is imperative.

The OSCE should replace the traditional examination for first and second year student nurses as well. It can also be adapted for the evaluation of ward sisters' and zone matrons administrative and other nursing skills. The latter application should not be viewed negatively by the categories of staff mentioned, but should be regarded as a learning experience as an aid in improving clinical competence. This is part of staff development.

Role play should be encouraged by the tutors at the Nursing Colleges. This should facilitate the development of verbalisation skills and should encourage spontaneity.
Adequate report back sessions should be arranged for the hospital and college staff. The teaching of administrative skills in the wards should receive greater attention.

\section{SECOND OSCE}

The second OSCE was conducted on 27 June 1984. Another group of thirs year student nurses was examined.

In general it was felt that. in all respects, it was a much more successful attempt than the first. The four major areas were again examined, but different stations were designed.

\section{CONCLUSION}

The traditional oral examination is useful in certain circumstances. but has limited advantages for the learner.

The OSCE method allows for the evaluation of the knowledge, psychomotor and affective skills of the learner. At Groote Schuur Hospital it will certainly be explored for its potential with regard to its application to other categories of nursing staff.

It should be remembered that:

Examinations are formidable even to the best prepared, for the greatest fool may ask more than the wisest man can answer. (Colton. p. 83:17).

\section{REFERENCES}

1. Hall-Turner. W.J.A (1983) Medical Education Vol. 17 112-119 March 1983

2. Kent. A P: Lazarus I. (1983) An ohjecrive medical student examination in obstetrics. S.A. Medical Journal. Рап (⿻十⺀. 10 September 1983

3. Lazarus. J: Kent A.P (1983) Student attitudes towards the objective structured clinical examination (OSCE) and conventional methods of assessment. S.A. Medical Journal, Part 64, 10 Septemher 1983

4. Sheahan, John (1979) Measurement in nursing cducation. Journal of adianced nursing 1979. 4

5. Van Niekerk. J.G.P. Lomhard S.A. (1982) The OSCE - Experiment at Medunsa. Curutionis. Vol 5 No 1 March 1982

6. S.A. Nursing Council Regulation, No R879 of $2 \mathrm{May}$ 1975 as amended

7. Colton. C.C. (1983) Colltus Concise Derwenary of Qursa. vions. 